\title{
「公正」な職場は, 罪からの立ち直りを支えるか
}

一組織的公正性および公正世界信念が有前科者に対する受容に及ぼす影響—

○六瀬 貴大 $^{1} \cdot$ 藤 桂 $^{2}$

(法務省 ${ }^{1} \cdot$ 筑波大学 $\left.{ }^{2}\right)$

キーワード : 有前科者, 許し, 組織的公正性

Can "justice" in workplace support re-entry from a criminal ? : The influence of organizational justice on the forgiveness and acceptance to the person with a criminal record.

Takahiro Rokuse ${ }^{1}$ and Kei Fuji ${ }^{2}$

(Ministry of Justice ${ }^{1}$, University of Tsukuba ${ }^{2}$ )

Key Words: The person with criminal record, Forgiveness, 0rganazational justice

\section{問題と目的}

有前科者に対し, 社会での「居場所」と「出番」を確保す ることの必要性が主張されている。法務省では, 有前科者の 居場所や出番を確保するため, 有前科者と知りながら雇用を 行う協力雇用主の開拓に努めており, 現在では2万を超える事 業主の登録がなされている（法務省,2018）。しかし一方で, 実際に有前科者を雇用する協力雇用主の数は約 900 に留まり

（法務省,2017），かつ，雇用主された有前科者の半数が半年 以内に職場を辞めている現状もある（法務省，2018）。この 問題を解決するためには，有前科者本人のみならず，有前科 者を受け入れる側としての周囲の人々の感情や対応にも着目 する必要がある。

この問題に関して六瀬・遠藤・藤 (2018) で

は, Forg ivenessおよびその阻害要因に関する知見（例えば Exl ine \& Baumeister,2003; Raj \& Wiltermuth, 2016など) に基づき，大学生を対象とした場面想定法による調査を行っ ている。その結果，「世界は公正であるべき」と考える公正 世界信念の中でも, 究極的公正世界信念が強い者は, Revenge 動機を媒介して有前科者への受容的な行動を抑制する一方 で，内在的公正世界信念が強い者ほど，有前科者への受容的 行動を行いやすいことを示している。すなわち有前科者を受 け入れる側において, 公正世界信念は受容的行動を規定する 重要なファクターであることを明らかにしている。

しかし，実際の職場において有前科者と接するのは，大学 生よりもむしろ社会人が多いと考えられる。すなわち六瀬他

（2018）のように大学生のみならず, 社会人を対象とした検 討も行う必要がある。そこで本研究では第一に, 現職の社会 人を対象として調査を実施し, 六瀬他（2018）で示された過 程が見られるかを検討する。

加えて, 公正世界信念とは, 幼少期以降の経験を通して形 成され，さらに報酬や罰の経験を通して強化されるものとさ れている(Bennett,2008)。加えて, 公正世界信念はライフス トーリーの中で強められる可能性もあると想定されており

(Lerner,1980)，各発達段階での様々な経験や環境・状況と の相互作用を通して, 公正世界信念の強弱は変わっていくも のと考えられる。こうした知見に基づけば，個人が所属して いる環境が, 公正性を強く追求するものである場合, その個 人の公正世界信念も強められる可能性が予測される。特に, 社会人を取り巻く環境における公正性に関しては, 所属する 組織が自分のことをどの程度公正に扱っているかを評価す る, 組織的公正性（例えば, Inoue et al., 2009) が挙げら れる。そこで本研究では第二に, 所属している職場における 組織的公正性が, 公正世界信念, そして有前科者に対する Forg ivenessおよび受容的行動にどのような影響を及ぼすかを 検討する。

\section{方 法}

調査対象：（株）クロス・マーケティングの登録モニター
のうち，組織に勤める社会人を対象にWeb調査を実施し，400 名 (男性 266 名, 女性 134 名; 平均 47.65 歳, $\mathrm{SD}=$ 9.82）の回答を得た。

質問紙の構成：（1）有前科者へのForgivenessおよび受容的 行動：予備調査を基に作成した，「同じ勤務先で働いている 同僚が，実は，過去に罪を犯し刑務所に入っていたことがわ かった」という場面を提示し想定するよう求めた。次に有前 科者に対するForg ivenessとして，TRIM-12(McCul lough, et al., 1998)を，原著者の許可を得た上で有前科者用に文言を 修正した 12 項目を尋ねた（5件法）。加えて，有前科者に対す る受容的行動として，六瀬他（2018）で作成した13項目を尋 ねた（5件法）。（2）公正世界信念：村山・三浦（2015）の 公正世界信念尺度（12項目，6件法）。（3） Inoue et al. （2009）の日本語版組織的公正性尺度（1 3 項目，5件法）。

（4）個人属性など。

\section{結果と考察}

組織的公正性 $\rightarrow$ 公正世界信念 $\rightarrow$ Forg iveness $\rightarrow$ 受容的行動と いうモデルを想定し, 共分散構造分析を行った(Figure 1)。 その結果，六瀬他（2018） と同様，社会人においても，究極 的公正世界信念はRevenge動機を増大させ受容的行動を抑制す ること, その一方で内在的公正世界信念はRevenge動機を低減 し受容的行動を促進することが示された。

さらに，組織の意思決定の公正性に関する「手続き的公正 性」は, 究極的公正世界信念と内在的公正世界信念の両方を 強めていた。その意味で, 働く個人が認知する組織における 手続き的公正性の高さは，必ずしも有前科者に対する Forgivenessや受容的行動を促すわけではなく，時として排斥 的な反応をもたらす要因となる可能性もあることが示され た。しかし同時に, 上司が，部下に対し公正に接しているこ とを示す「相互作用的公正性」は, 係数は小さいもの の, Revenge動機を抑制するとともに，受容的行動を促進して いた。どのような部下にも公平に接する上司の下では, その 態度が一種の模範として部下にも受け入れられ，ゆえに同僚 が有前科者であると判明したとしても変わらぬ公平な態度を 維持しようとする可能性が推察される。

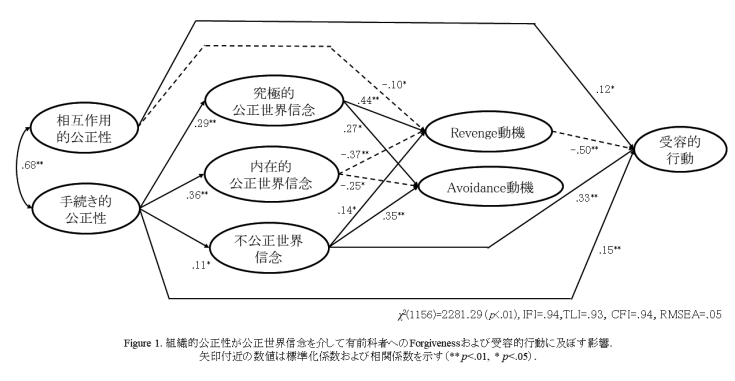

